\title{
Kreativitas Ide Pahlawan Sejati (Iklan Bukalapak Tahun 2016)
}

\author{
Hansen Hindharta, Gregorius Genep Sukendro \\ hansenhindharta@gmail.com, geneps@untar.ac.id \\ Fakultas Ilmu Komunikasi Universitas Tarumanagara
}

\begin{abstract}
Hero is a activity within sacrifice in an activity. But most people thought that hero is a heroic activity with bloodshed. In reality, we can meet hero activity in relationship with family or our couple. In this research will be explain about creativity idea advertise from "Pahlawan Sejati". This advertise has a concept: a man has sacrifice his crush for other man. Hero according to W.J.S Poerwadarminta in Kamus Besar Bahasa Indonesia 2006:695 is a person or warrior who bravely and manly. This research will find out how the director has the idea until he found a romance hero idea with a heartfelt. Conclusion, in the present, hero is not always a people heroic attitude with gun to defend something.
\end{abstract}

Keywords: Hero, romance, creative idea, hero with a gun, bukalapak advertise

\begin{abstract}
Abstrak
Pahlawan merupakan suatu bentuk aktivitas yang dinyatakan banyak orang sebagai kerelaan berkorban dalam suatu kegiatan. Namun masyarakat masih banyak yang mengira bahwa pahlawan harus dalam konteks aktivitas yang heroik dan ada unsur pertumpahan darah. Pada nyatanya aktivitas pahlawan dapat ditemukan pada percintaan. Dalam penelitian ini tentu akan membahas terkait kreativitas ide iklan Pahlawan Sejati yang mengangkat konsep Pahlawan Percintaan yang rela mengorbankan perasaannya demi kebaikan perempuan yang sang laki-laki sayangi sejak kecil. Pahlawan menurut W.J.S Poerwadarminta yang ditulis pada Kamus Besar Bahasa Indonesia 2006:695 adalah seseorang atau pejuang yang gagah berani (Majalah ARSIP Edisi 642014 :14). Penelitian ini pula ingin mengetahui bagaimana sang sutradara memiliki ide tersebut dan mem-breakdown-nya, hingga menemukan ide pahlawan percintaan yang penuh dengan ikhlasan hati. Kesimpulannya bahwa wujud atau sosok pahlawan saat ini tidak harus menunjukkan sikap heroik dan angkat senjata untuk membela suatu hal.
\end{abstract}

Kata Kunci: Pahlawan, percintaan, ide kreatif, pahlawan angkat senjata, iklan bukalapak

\section{Pendahuluan}

Semakin pesatnya perkembangan dunia audio visual diiringi dengan banyaknya iklan-iklan dengan ide menarik. Ide iklan yang diambil pun beragam, bahkan dapat dikaitkan dengan hari raya nasional, salah satunya adalah Kemerdekaan Republik Indonesia. Tema yang dapat diambil dari hari raya tersebut adalah pahlawan. Pahlawan memang wujudnya saat ini tidak seperti zaman penjajahan dahulu. Kini pahlawan adalah orang yang berjasa dalam suatu kegiatan tanpa pamrih dan tidak harus selalu membela negara untuk kemerdekaan. Namun bentuk kemerdekaan untuk diri sendiri atau membahagiakan orang lain merupakan bentuk dari usaha pahlawan. Jika dikaitkan dengan iklan, pembuatannya pun tidak luput dari para kreator kreatif yang dapat mengeksekusi ide menarik mereka dengan baik. Salah 
satunya adalah komunitas Digital Cinenatography Indonesia (DCI). Beberapa anggotanya dari regional Jakarta Selatan mengikuti Festival Iklan Bukalapak pada tahun 2016 lalu, mereka membuat iklan Pahlawan Sejati yang menjadi juara 1.

Dalam penelitian ini akan mencari tahu apakah pahlawan betul-betul tidak harus menunjukkan hal yang membela suatu negara atau tidak. Kemudian ingin mencari tahu langkah yang dilakukan sang sutradara dan konseptor dalam menemukan ide Pahlawan Sejati tersebut. Iklan 30 detik ini dijadikan karena menyajikan suatu aksi kepahlawanan dengan unsur komedi romantis. Kemudian diharapkan dengan penelitian ini, ke depannya masyarakat akan lebih paham bahwa aksi sekecil apapun dalam membantu orang lain merupakan wujud pahlawan. Terutama dalam bidang videografi dan sinematografi, ketika ingin menyajikan ide pahlawan, dapat memiliki pertimbangan dalam mengeksekusi iklannya tersebut dengan baik. Lalu peneltian ini akan mengacu pada teori pahlawan menurut W.J.S. Poerwadarminta dan juga hasil wawancara dengan narasumber yang kompeten di bidangnya.

\section{Metode Penelitian}

Metode yang digunakan dalam penelitian ini adalah pendekatan kualitiatif dengan analisis deskriptif untuk mengetahui proses pembuatan ide kreatif iklan Pahlawan Sejati yang menjadi bahan penelitian dari penulisan skripsi ini. Deniz dan Lincoln dalam Moleong (2009) menyatakan bahwa penelitian kualtitatif adalah penelitian yang menggunakan latar ilmiah, dengan maksud menafsirkan fenomena yang terjadi dan dilakukan dengan jalan melibatkan berbagi metode yang ada. Metode yang biasanya dimanfaatkan adalah wawancara, pengamatan dan pemanfaatan dokumen penelitian kualitatif.

Dalam penelitian kualitatif dikhususkan untuk meneliti dengan cara terjun langsung ke lapangan untuk mengetahui secara dekat objek yang sedang ditelitinya. Tentu hal ini sangat berbeda dengan metodologi penelitian kuantitatif yang meneliti suatu objek menggunakan angka statistik ataupun mengambil suatu sampel dari variabel penelitiannya. Maka dari itu dalam penelitian ini, penulis memilih metodologi kualitatif sebagai acuan untuk mencari tahu objek yang diteliti.

\section{Hasil Temuan dan Diskusi}

Setiap iklan tentu memiliki ide-ide kreatif dibalik pembuatannya, salah satunya adalah iklan Pahlawan Sejati ini yang dikemas ke dalam bentuk komedi romantis. Rangga Kusmalendra (Mang Kus) sebagai konseptor menjelaskan pada video "Sharing Ide Iklan 30 Detik Senilai Rp250 Juta" bahwa iklannya tersebut tentu harus dihubungkan terlebih dahulu dengan brief yang diinginkan panitia Festival Iklan Bukalapak. Setelah dihubungkan melalui proses brainstorming,

Mang Kus dalam videonya menjelaskan bahwa ingin video bertemakan pahlawan seperti dengan brief akan tetapi tidak ingin yang mainstream. Mang Kus akhirnya menemukan 1 kata kunci yaitu komedi romantis. Dari komedi romantis tersebut kemudian diturunkan menjadi beberapa bagian kecil atau disebut tahap breakdown. Dari romantis kemudian akan muncul kata cinta, Mang Kus membagi cinta ke dalam 4 bagian, yaitu: dua sejoli, keluarga, negara, dan Tuhan. Kemudian yang dipilih dalam ide iklan ini adalah dua sejoli, dari hubungan tersebut ada yang 
berhasil dan gagal. Mang Kus berpikir bahwa memperjuangkan cinta yang berhasil sudah biasa, maka dari itu di ambil lah cinta yang gagal.

Gambar 1. Tangkapan Layar Video Rangga Kusmalendra

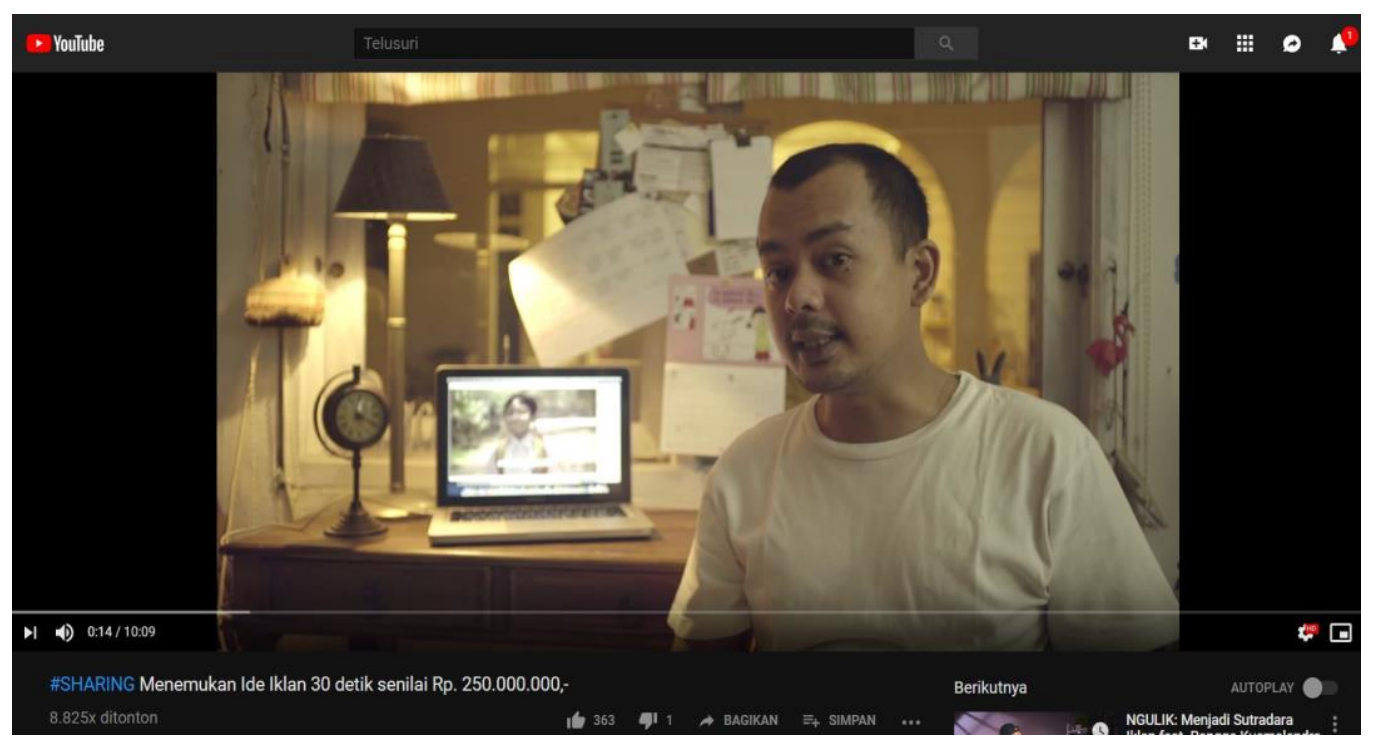

Sumber: Dokumentasi Peneliti (2018)

Mang Kus dalam videonya menjelaskan bahwa ingin video bertemakan pahlawan seperti dengan brief akan tetapi tidak ingin yang mainstream. Mang Kus akhirnya menemukan 1 kata kunci yaitu komedi romantis. Dari komedi romantis tersebut kemudian diturunkan menjadi beberapa bagian kecil atau disebut tahap breakdown. Dari romantis kemudian akan mencul kata cinta, Mang Kus membagi cinta ke dalam 4 bagian, yaitu: dua sejoli, keluarga, negara, dan Tuhan. Kemudian yang dipilih dalam ide iklan ini adalah dua sejoli, dari hubungan tersebut ada yang berhasil dan gagal. Mang Kus berpikir bahwa memperjuangkan cinta yang berhasil sudah biasa, maka dari itu diambillah cinta yang gagal. Namun dari cinta yang gagal tersebut, ditemukan lagi bahwa ada yang ikhlas menerima hal tersebut atau umumnya disebut ikhlas. Dari kata ikhlas tersebutlah menjadi muncul gambaran kasar dari ide iklan pahlawan sejati ini.

Setelah dirasa matang dengan adanya ide kasar tersebut, Mang Kus membuat storyboard kasar menggunakan potongan-potongan gambar atau adegan yang ada pada iklan Bukalapak sebelumnya atau stok foto. Storyboard tersebut berguna sebagai gambar setiap adegan untuk mengambil angle dan detil yang ada. Di dalam storyboard tersebut cukup menjelaskan setiap adegan yang tersaji dalam iklan yang telah tayang tersebut. Setelah pembuatan storyboard, Mang Kus membuat naskah iklan Pahlawan Sejati ini. Dalam naskah tersebut ada beberapa adegan atau frame yang dihilangkan lantaran keterbatasan durasi yang hanya diperbolehkan selama 30 detik untuk festival iklan tersebut. Mang Kus dalam video penjelasannya memaparkan bahwa tantangan dalam membuat iklan 30 detik ini adalah ketika dapat memasukan inti cerita dan dipadukan dengan produk Bukalapak secara mulus atau tanpa memaksa. 
Gambar 2. Naskah Iklan Pahlawan Sejati

Bukalapak "Pahlawan sejati"

\begin{tabular}{|c|c|c|}
\hline SC. & VISUAL & AUDIO \\
\hline 1 & $\begin{array}{l}\text { Present Day. } \\
\text { Dari tampak belakang, seorang pria sedang duduk di mejanya (malam hari) }\end{array}$ & \\
\hline 2 & $\begin{array}{l}\text { Flash back SD. } \\
\text { Sebuah balon terbang tinggi, tampak seorang gadis cantik bernama Sarah (SD) } \\
\text { menangis balon nya terbang. } \\
\text { Lalu muncul Hero kita memberikan balonnya. }\end{array}$ & "Dari kecil, aku selalu ingin jadi pahlawanmu" \\
\hline 3 & $\begin{array}{l}\text { Flash back SD. } \\
\text { Sarah SD lagi nunggu hujan di depan sekolahnya, lalu Hero SMP menghampirinya } \\
\text { dan memberikan payung. } \\
\text { Si Hero dengan badan yang kebasahan tampak bersin-bersin } \\
\end{array}$ & "Pelindungmu" \\
\hline 4 & $\begin{array}{l}\text { Flash back SD. } \\
\text { Sarah SD pakai baju pramuka lagi jurit malam senternya abis batere.. } \\
\text { Hero SD datang ngasih senternya. } \\
\text { Si Hero yang gak punya senter di gelapnya malam malahan kejeblos lubang } \\
\text { Ngusruuk "Mamaaah!!" }\end{array}$ & "Cahaya hidupmu" \\
\hline 5 & $\begin{array}{l}\text { Cut to Present Day. } \\
\text { Tampak tangan sedang menklik tombol jual di Bukalapak. } \\
\text { Di teras rumah Steven tampak sedang mengobrol dengan Sarah. }\end{array}$ & $\begin{array}{l}\text { Steven : Neng, doain dagangan Aa laku ya, biar kita jadi nikah. } \\
\text { Sarah : lya A, sarah mengangguk sambil tersenyum }\end{array}$ \\
\hline 6 & $\begin{array}{l}\text { Ketika Steven pulang, ternyata ada seseorang yang memperhatikan dan menguping } \\
\text { pembicaraan mereka }\end{array}$ & \\
\hline 7 & $\begin{array}{l}\text { Cut to set scene 1. pria tadi dengan jari gemetar mengklik dagangan dari Steven } \\
\text { Tadi dengan jumlah banyak. }\end{array}$ & \\
\hline 8 & $\begin{array}{l}\text { Cut Steven yang sumringah memberitahukan Sarah bahwa mereka jadi menikah. } \\
\text { Dengan mulut gerakan slomo mengucapkan (kita nikah..) } \\
\text { Dikejauhan tampak ada yang memperhatikan. Lalu kemudian balik badan }\end{array}$ & "Dan sampai kapanpun.." \\
\hline 9 & $\begin{array}{l}\text { Laki-laki itu berjalan, kamera follow dari samping, ketika kamera melewati pohon, } \\
\text { laki-laki itu berubah menjadi Hero kita. }\end{array}$ & Aku akan selalu menjadi pahlawan mu.. \\
\hline 10 & & Karena pahlawan sejati selalu ikhlas memberi.. \\
\hline
\end{tabular}

Sumber: Dokumen Pribadi Rangga Kusmalendra (2017)

Gambar 3. Tampilan Storyboard Iklan Pahlawan Sejati

\section{Director's Storyboard - 30sec}

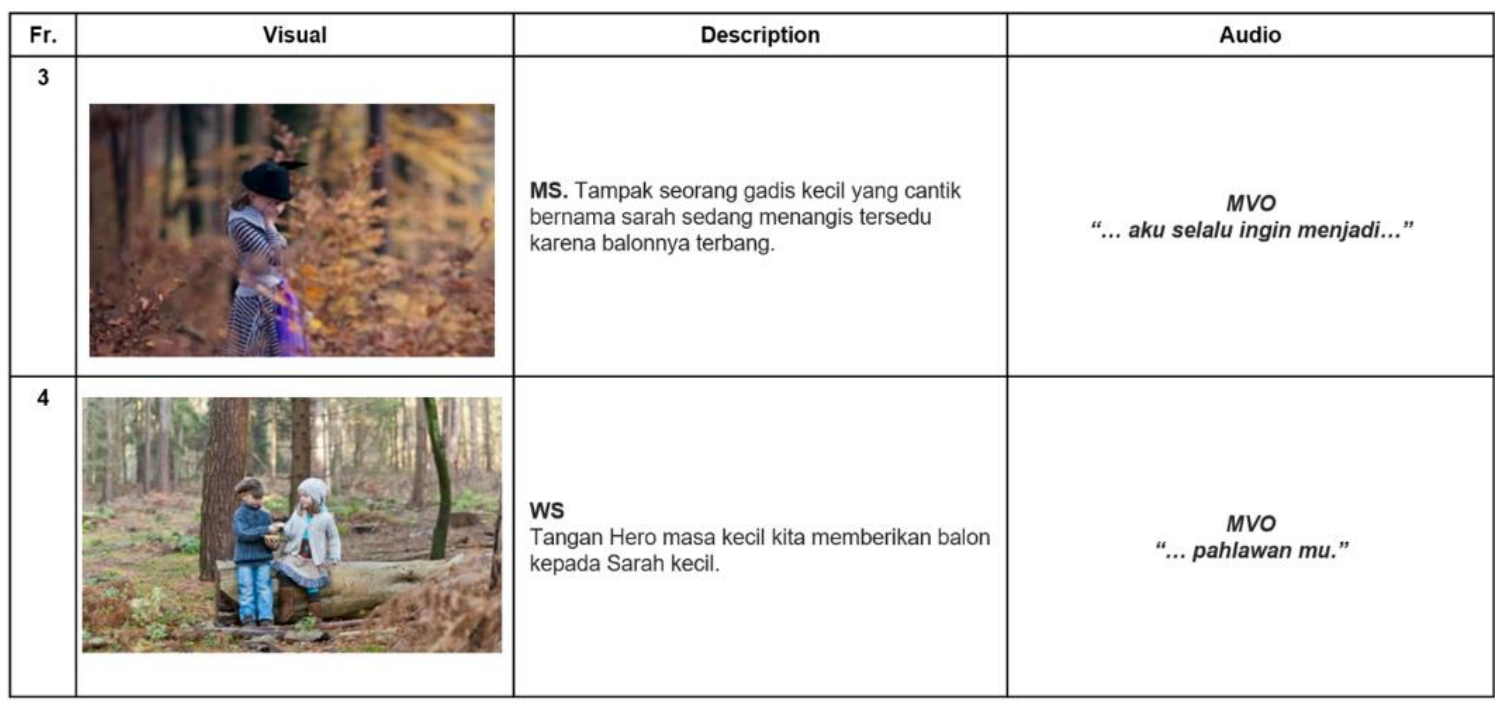

Sumber: Dokumen Pribadi Rangga Kusmalendra (2017)

Iklan Pahlawan Sejati merupakan suatu bentuk interpretasi ide kreatif iklan yang berhasil dieksekusi dengan pendekatan pahlawan percintaan. Dalam hal ini percintaan yang bertepuk sebelah tangan, menerima dengan penuh keikhlasan hati. Karena menurut Mang Kus (Konseptor iklan Pahlawan Sejati), cinta yang bertepuk sebelah tangan ada yang negatif dan positif. Ide iklan ini dimulai dari sisi positif yaitu suatu keikhlasan hati. 
Ide kreatif iklan ini dimulai dari pencetusan kalimat komedi romantis. Maka dari itu sebetulnya iklan ini tidak sepenuhnya membahas tentang pahlawan. Pahlawan perasaan dalam ide iklan Pahlawan Sejati ini sebetulnya hanya turunan dari pemikiran awal kata "Komedi Romantis" menurut Mang Kus dalam video penjelasan ide iklan Pahlawan Sejati. Terlihat dari turunan ide komedi romantis, ada cinta yang tidak harus memiliki dan keikhlasan. Ikhlas ini yang dijadikan Mang Kus sebagai kata kunci untuk dihubungkan ke brief pahlawan dari Bukalapak.

Jika dikaitkan dengan kerangka pemikiran, pertama akan membahas dari segi ide. Menurut Plato, ide merupakan sesuatu yang memimpin pemikiran manusia (Hadiwijono, 2005:41). Iklan Pahlawan Sejati telah memiliki suatu rancangan pemikiran yaitu dari kata kunci "komedi romantis", kemudian Mang Kus menggagas beberapa turunan ide awal seperti cinta kepada negara, dua sejoli, keluarga, dan Tuhan. Setelah turunan tersenut, pada akhirnya Mang Kus sebagai konseptor memiliki tujuan akhir atau cita-cita dalam pemikiran ide ini yaitu pahlawan cinta dengan penuh keikhlasan.

Menurut peneliti jika membahas dari teori ide ini yang dikaitkan dengan ide iklan pahlawan sejati, proses awalnya sudah cukup baik. Ide iklan Pahlawan Sejati dipikirkan secara matang dan di breakdown dari kalimat "komedi romantis" di turunkan ke cinta dua sejoli, negara, keluarga, dan Tuhan. Dari cinta dua sejoli ada cinta yang berhasil dan gagal. Mang Kus memilih cinta yang gagal karena dinilai lebih menarik. Dari cinta yang gagal ternyata ditemukan bahwa cinta tidak harus memiliki. Dari sana muncul pemikiran bahwa cinta yang ditolak akan berdampak negatif dan positif. Mang Kus mengambil dari sisi positif yaitu keikhlasan hati menerima cintanya tidak diterima.

Dari pemaparan ide iklannya tersebut, sudah terlihat adanya suatu kedalaman pembentukan ide yang sangat baik. Ide iklan dipikirkan secara matang melalui breakdown yang telah disebutkan sebelumnya. Breakdown iklan dilakukan dengan sangat sederhana namun langsung kepada poin yang sebetulnya ingin dituju. Urutan pembedahan ide utamanya pula memang sesuai dengan realita yang ada di kehidupan saat ini. Bicara tentang iklan memang tidak luput dari ide dan kreativitas. Tiga elemen tersebut saling berhubungan satu sama lain. Iklan merupakan pengemasan informasi dalam proses komunikasi yang disebarkan untuk mempengaruhi dan menarik minat seseorang, sekelompok orang atau siapa saja yang ingin menjual. Kekuatan periklanan memang terletak pada kecanggihan, kepiawaian dalam merumuskan ataupun mengorganisasikan pesan-pesan menarik perhatian dan mampu membangun pemaknaan bersama antara pengirim pesan iklan dengan khalayak. (Eko Harry, Dinamika Pesan Iklan, Vol 6 No. 2:2014).

Mengacu pada teori iklan tersebut, iklan pahlawan sejati memang sudah cukup kreatif menyajikan pahlawan romantis atau dalam penelitian ini disebut dalam idenya adalah komedi romantis. Iklan pahlawan sejati dapat dikemas menggunakan pendekatan perasaan, Akan tetapi, iklan ini tidak menampilkan aplikasi ataupun cara membeli barang di Bukalapak untuk menggugah minat penonton dalam berbelanja di Bukalapak. Dalam video penjelasan Mang Kus, beliau juga tidak ada menjelaskan hal tersebut, namun ada 1 hal yang bisa dikaitkan adalah ketika tema komedi romantis dikaitkan dengan produk Bukalapak secara softselling. Menurut peneliti, hal ini lah yang menjadi ketidaksesuaian dengan teori iklan yang dikutip.

Iklan pahlawan sejati ini memang mengangkat tema pahlawan yang dikaitkan dengan komedi romantis. Namun pahlawan menurut W.J.S Poerwadarminta yang ditulis pada Kamus Besar Bahasa Indonesia 2006:695 adalah seseorang atau pejuang 
yang gagah berani (Majalah ARSIP Edisi 64 2014:14). Menurut Kolonel Infantri Kristomei Sianturi, Kepala Penerangan Kodam Jaya (Kapendam Jaya), bahwa pahlawan memang betul tidak harus mereka yang berjuang untuk negara, akan tetapi dengan kita membiayai keluarga sendiri, membantu orang lain demi kebaikan diri mereka itu merupakan wujud pahlawan. Pahlawan juga sifatnya diakui oleh orang lain dan tidak boleh mengakui diri sendiri sebagai pahlawan. Karena pahlawan adalah orang yang berjasa tanpa pamrih. Masih dalam hasil wawancara dengan Kapendam Jaya, bahwa pahlawan percintaan juga wujudnya sama seperti pahlawan untuk kebaikan orang lain. Kita mempertahankan dan berbuat kebaikan demi hubungan dengan kekasih berjalan baik, itu adalah wujud pahlawan dalam percintaan.

Selain itu iklan ini juga dikomentari oleh Creative Director dari PT Media Optima Kreasi Utama (MOKU Production House), Rico Kevin, beliau menjelaskan bahwa iklan ini masih bisa dikembangkan lagi dalam segi cinematic dan musik yang dramatis. Sang sutradara harus dapat mengemas ide iklan dengan berbagai gaya eksekusi seperti iklan sabun Ake dari Thailand yang menjadi acuan oleh Rico Kevin. Menurut Rico Kevin, iklan Pahlawan Sejati ini masih kurang berimbas pada makna pahlawan, namun lebih dominan ke arah cinta bertepuk sebelah tangan.

\section{Simpulan}

Iklan pahlawan sejati memiliki makna pahlawan yang sudah cocok jika dikaitkan dengan komedi romantis, Pengurangan adegan dari rencana awal sudah cukup membuat iklan berdurasi 30 detik ini menyampaikan pesan pahlawan tersiratnya tersebut. Sebagai pemenang Festival Iklan Bukalapak Tahun 2017, Pahlawan Sejati cocok untuk dijadikan panutan untuk pembuatan iklan bertemakan pahlawan, karena unsur ini tidak selalu harus mengangkat senjata, berpakaian layaknya super hero atau sebagai pahlawan membela negara.

Faktanya unsur pahlawan dapat dikemas dengan cara beragam, salah satunya dikehidupan nyata pula, kita bisa menjadi pahlawan untuk orang lain. Sekecil apapun hal yang dilakukan, bila itu ditujukan untuk membantu dengan ikhlas dan tanpa pamrih, itulah disebut pahlawan. Namun bentuk pahlawan tersebut tidak bisa disalah artikan dengan kita selalu membantu orang dan ingin disebut dirinya sebagai pahlawan. Mengacu pada kata tanpa pamrih, maka dari itu jika telah membantu orang lain, biarkan yang kita bantu menilainya. Hal ini yang dapat digaris bawahi oleh para pembuat iklan masa kini jika ingin mengambil tema pahlawan. Karena jika melihat dari para kontestan Festival Iklan Bukalapak rata-rata mereka membuat ide iklannya selalu terkait dengan unsur pahlawan mulai dari superhero hingga veteran perang zaman Belanda. Tentu hal ini sudah biasa dan banyak masyarakat yang akan berpendapat sama bahwa bentuk pahlawan adalah seperti iklan-iklan tersebut.

Seperti salah satu pemenang dalam Festival Iklan Bukalapak berjudul Doea Senja, video iklan tersebut masih mengambil tema pahlawan veteran Tanah Air yang bernostalgia dalam perang dengan bermain gim playstation. Iklan tersbeut masih kental dengan nuansa pahlawan perang yang membela tanah air, namun bisa dikemas dengan komedi. 
Gambar 4. Cuplikan Adegan Doea Senja, Juara 2 Festival Iklan Bukalapak Tahun 2017

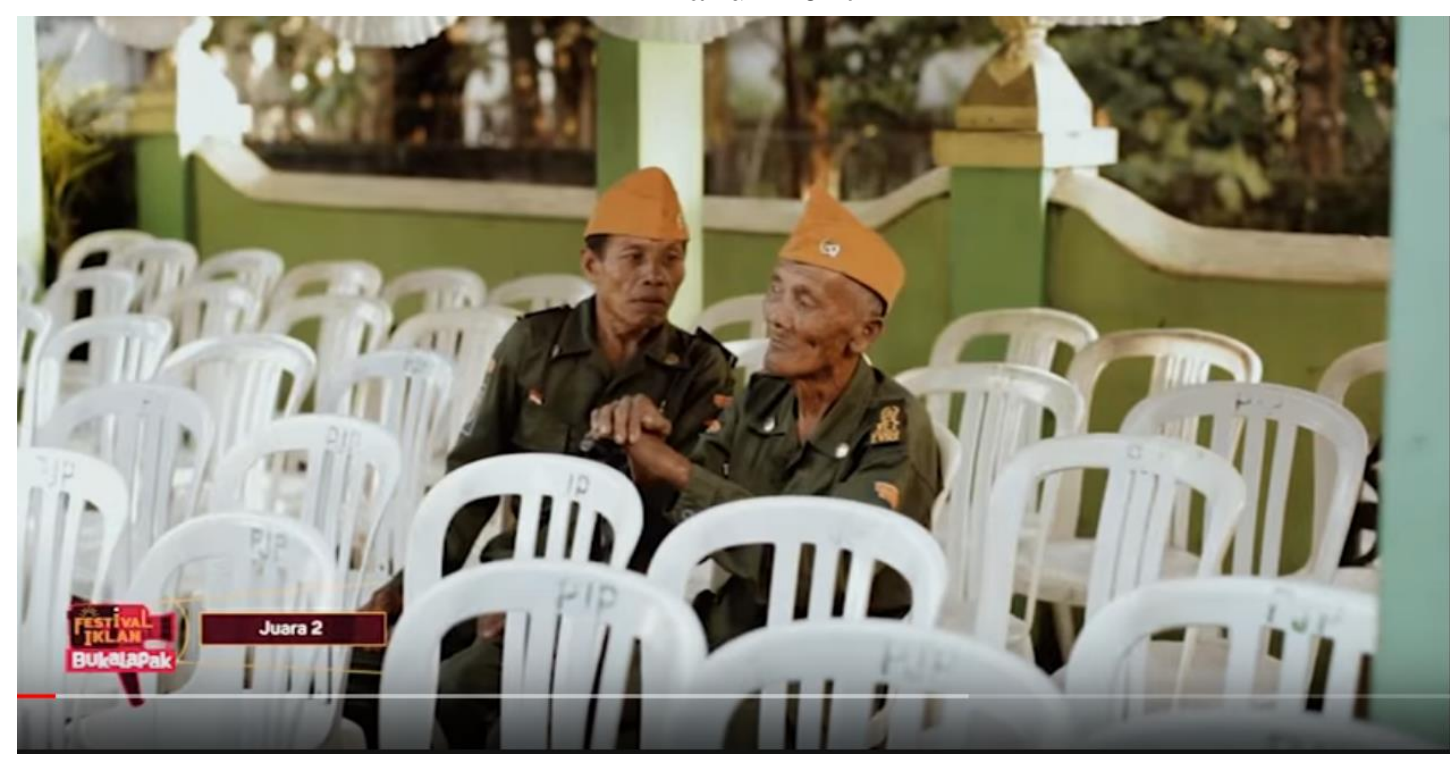

Sumber: Dokumentasi Peneliti (2018)

Jika dibandingkan dengan iklan Pahlawan Sejati, tentu akan berbeda. Dalam iklan Pahlawan Sejati sama sekali tidak menampilkan unsur pahlawan yang selama ini sudah menjadi image umum di masyarakat. Dalam iklan tersebut menampilkan ide komedi romantis dibalut dengan pahlawan percintaan yang rela mengorbankan perasaannya. Akan tetapi menurut narasumber peneliti, iklan ini bisa dikembangkan lagi dari segi cinematic yang lebih menampilkan kepahlawanan secara tidak langsung dan musik-musik dramatis. Namun tetap mempertahankan pahlawan yang tidak selalu menampilkan aksi heroik. Ini menjadikan iklan Pahlawan Sejati sebagai nilai plus dari pada pesaingnya. Kreator iklan juga bisa menerapkan ide kreatif seperti ini. Jika berbicara iklan untuk festival, memang tidak luput dari ide kreatif yang terkadang sulit untuk masuk ke nalar. Iklan Pahlawan Sejati ini sudah cukup membuat penonton berpikir dua kali dalam mencari makna konsepnya, karena sejatinya ide iklan dalam sebuah festival karya harus unik dan anti-mainstream. Rangga Kusmalendra berhasil mengemas idenya menjadi iklan yang kreatif dalam mengolah pesan/creative brief dari Bukalapak.

\section{Ucapan Terima Kasih}

Peneliti ingin berterima kasih kepada seluruh kerabat dan narasumber yang telah berkontribusi dalam penulisan penelitian ini, terutama kepada Bapak Kolonel Infanteri Kristomei Sianturi selaku Kepala Penerangan Kodam Jaya (Kapendam Jaya), beliau telah meluangkan waktunya sebagai narasumber penulis dalam menjelaskan makna pahlawan sesungguhnya. Dari beliau, penulis mendapatkan banyak pengetahuan baru di bidang pahlawan terutama pengalaman beliau di bidang militer. Kedua, penulis berterima kasih kepada Bapak Rico Kevin selaku Creative Director dari PT Media Optima Kreasi Utama (MOKU Production House). Beliau telah memberikan masukan terkait penelitian ini dari bidang konsep iklan. Tentu masukan beliau sangat bermanfaat dalam pengembangan penelitian ini, karena menjadi cukup banyak pertimbangan selain adanya makna pahlawan yang dijelaskan oleh Bapak Kapendam Jaya. 
Vol. 2, No. 2, Desember 2018, Hal 347 - 354

\section{Daftar Pustaka}

Arsip Edisi 64. (2014). Nilai-Nilai Kepahlawanan. Jakarta: Arsip Nasional Republik Indonesia.

Hadiwijono, Harun. (2001). Sari Sejarah Filsafat Barat 2. Yogyakarta: Kanisius.

Moleong, Lexy J. (2009). Metode Penelitian Kualitatif. Bandung: Remaja Rosdakarya.

Susanto, E. (2016). Dinamika Pesan Iklan. Jurnal Komunikasi, 6 (2), 1-9. Retrieved from https://journal.untar.ac.id/index.php/komunikasi/article/view/28 